\title{
RANCANG BANGUN MESIN PENCACAH GEDEBOG PISANG UNTUK MENINGKATKAN PRODUKSI PAKAN TERNAK KAMBING DENGAN SISTEM FERMENTASI DI KELURAHAN SUMBEREJO
}

\author{
Abdul Rohman ${ }^{1)}$ M. Abdul Wahid ${ }^{2)}$ Sari Wiji Utami ${ }^{3)}$ \\ Anis Usfah ${ }^{(4)}$ \\ Staf Pengajar Program Studi Teknik Mesin ${ }^{(1,2)}$ Politeknik Negeri Banyuwangi, Jl. Raya Jember km13 \\ Banyuwangi \\ rahmanabdepoliwangi.ac.id \\ wahied poliwangi@yahoo.co.id \\ Staf Pengajar Program Studi Teknik Pengolahan Hasil Ternak ${ }^{(3,4)}$ Politeknik Negeri Banyuwangi, Jl. Raya \\ Jember km13 Banyuwangi \\ sariwijiutamiegmail.com \\ anis.usfah@poliwangi.com
}

\begin{abstract}
Abstrak
Gedebog pisang atau yang lebih di kenal Gedebog merupakan salah satu bagian dari pohon pisang yang dianggap sebagai limbah. Umumnya gedebog yang dianggap limbah sering dibuang begitu saja,belum adanya informasi bahwa limbah ini dapat dioptimalkan menjadi berbagai bahan yang mempunyai nilai jual dan dapat dijadikan usaha yang mempunyai keuntungan yang menjanjikan. Ketersedian bahan baku yang melimpah di sekitar lingkungan kelurahan serta harga bahan yang sangat terjangkau. Dari kondisi seperti di atas, kami melakukan pelatihan pembuatan pakan ternak fermentasi dan merencanakan mesin pencacah gedebog yang digunakan untuk mencacah gedebog pisang dengan ukuran yang sama rata dan tidak memerlukan tenaga yang besar ketika mencacah gedebog pisang menjadi ukuran yang lebih kecil-kecil sebagai bahan pakan ternak. Sebagai upaya untuk memudahkan peternak dalam pengolahan gedebog pisang untuk dimanfaatkan sebagai bahan baku pakan ternak yang khususnya hewan kambing. Spesifikasi mesin pencacah gedebog pisang ini adalah menggunakan motor bakar (gasoline) dengan rasio kecepatan $1400 \mathrm{rpm}$ d Perencanaan daya motor sebesar 6,5 HP menggunakan diameter pulley penggerak $65 \mathrm{~mm}$ dan diameter pulley yang digerakkan $156 \mathrm{~mm}$, didapatkan putaran $500 \mathrm{rpm}$. Sistem transmisi menggunakan V-belt A. Diameter poros yang digunakan sebesar $25 \mathrm{~mm}$. Baut yang digunakan adalah M10. Pisau pada mesin pencacah ini berjumlah 3 buah dengan bahan stainless steel. Umumnya peternak belum mengetahui secara detail prosedur pembuatan pakan ternak kambing dari gedebog pisang dengan fermentasi.
\end{abstract}

Kata Kunci: gedebog, pencacah, pakan, fermentasi

\section{PENDAHULUAN}

Gedebog atau gedebog pisang merupakan salah satu bagian dari pohon pisang yang kurang dimanfaatkan dan dianggap sebagai limbah. keberadaan gedebog pisang hanya dianggap sebagai limbah yang sering kali dibuang begitu saja, tidak banyak yang tahu bahwa limbah dari buah pisang ini dapat dioptimalkan menjadi berbagai bahan yang mempunyai nilai jual serta dapat dijadikan bahan pakan ternak fermentasi. Cara feremntasi adalah dengan menambahkan bahan yang mengandung mikroba proteolitik, lignolitik, selulotik, lipolitik dan bersifat fiksasi nitrogen nonsimbiotik.

Ketersedian bahan baku (gedebog pisang) yang melimpah di tanah air serta harga bahan yang sangat terjangkau. Pengolahan gedebog pisang sebagai bahan pakan untuk ternak kambing diharapkan dapat menjadi terobosan bagi para peternak agar dapat meminimalkan biaya untuk opersional serta dapat mengurangi tenaga kerja karena tidak perlu merumput untuk mendapatkan pakan ternak mereka. Teknologi fermentasi cukup sederhana, mudah diterapkan dilapangan dan disosialisasikan ke masyarakat, khususnya peternak di kelurahan sumberejo. Kandungan gedebog pisang menurut analisi Laboratorium Ilmu Nutrisi dan Kimia Fakultas Pertanian dan Peternakan UIN Susuka Riaun Tahun 2015 antara lain : Bahan kering (BK). $87,7 \%$, abu 25,12\%, lemak kasar (LK) 14,23\%, serat kasar (SK) 29,40\%, protein kasar (PK) $3 \%$ termasuk asam amino, amine nitrat, glikosida, mengandung $\mathrm{N}$, glikilipida, vitamin $\mathrm{B}$, asam nukleat, bahan ekstrak tanpa nitrogen (BETN) 28,15\% termasuk karbohidrat, gula dan pati.

Bahan makanan yang telah mengalami fermentasi mempunyai kandungan dan kualitas gizi yang lebih baik dari bahan asalnya, karena mikroba bersifat katabolik atau memecah komponenkomponen kompleks menjadi zat-zat yang lebih sederhana, sehingga lebih mudah dicerna. Disamping 
itu, mikroba dapat pula menghasilkan asam amino dan beberapa vitamin seperti riboflavin, vitamin B12, provitamin A, dan dapat menghasilkan flavour yang lebih disukai serta dapat mengurangi racun atau anti nutrisi yang terdapat pada bahan.

\section{TARGET LUARAN}

Untuk itu, maka kegiatan pengabdian masyarakat di kelurahan sumberejo dalam produksi pakan ternak kambing siap saji dari fermentasi gedebog pisang sangat relevan dan urgen dilakukan. Oleh karena itu, kami mencoba membuat suatu perencanaan mesin pencacah gedebog pisang yang lebih sederahana dalam produktifitas, lebih efektif untuk mencacah gedebog pisang dengan ukuran yang sama rata dan tidak memerlukan tenaga yang besar ketika mencacah gedebog pisang menjadi ukuran yang lebih kecil. Mesin pencacah gedebog pisang ini diharapkan bisa membantu dalam memanfaatkan gedebog pisang dengan maksimal dan efektif, penulis mengharapkan agar mesin ini benar-benar dapat bekerja sesuai dengan harapan dan keinginan. Semoga alat ini dapat bermanfaat bagi para peternak untuk melakukan usaha dan membantu memanfaatkan gedebog pisang untuk alternatif bahan baku pakan ternak

\section{METODE PELAKSANAAN}

Alternatif pemecahan masalah yang akan dilakukan, yakni pelatihan pengolahan gedebog pisang melalui cara fermentasi. Metode kegiatan yang dilakukan adalah diawali dengan dijelaskan potensi gedebog pisang sebagai sumber pakan, cara fermentasi gedebog pisang yang menghasilkan pakan alternatif siap saji. Pengoperasian mesin pencacah gedebog pisang. Dilanjutkan dengan diskusi atau tanya jawab sebelum demo pembuatan pakan siap saji di salah satu kandang peternak (sebagai pilot area). Tahap akhir dilakukan evaluasi keberhasilan kegiatan. Dipilihnya alternatif ini untuk meningkatkan nilai guna dari gedebog pisang yang selama ini belum termanfaatkan secara tepat sesuai dengan potensinya.

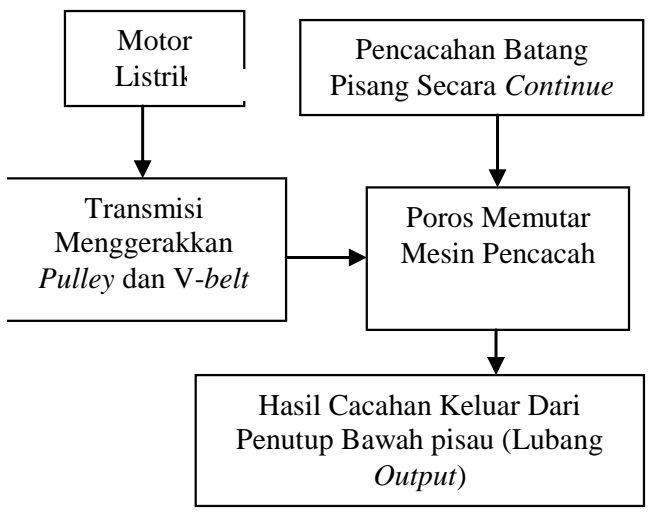

Gambar 1. Alur Kerja Mesin Pencacah Gedebog Pisang
Dalam mekanisme mesin pencacah gedebog pisang diketahui beberapa komponen-komponen utama apa saja yang dibutuhkan yang terlihat pada gambar berikut :

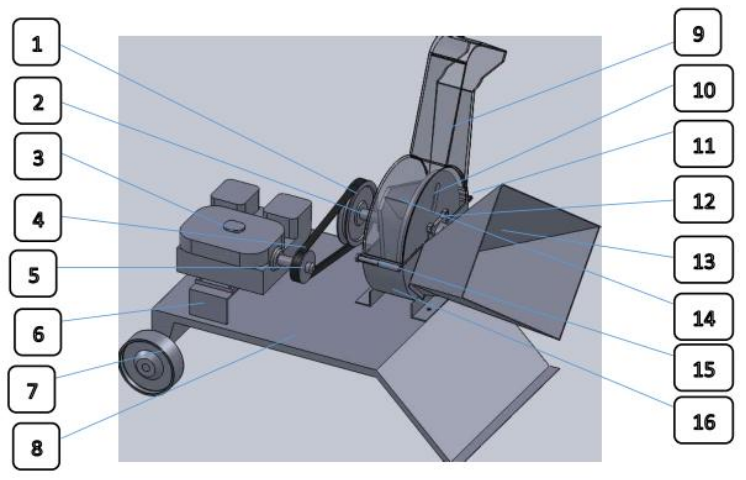

Gambar 2 Desain Mesin Pencacah Gedebog Pisang

Keterangan

$\begin{array}{lll}\text { 1. Pulley } & \text { 10. Poros, } \\ \text { 2. Poros, } & \text { 11. Motor Penggerak, } \\ \text { 3. Motor Penggerak, } & \text { 12. V-Belt, } \\ \text { 4. V-Belt, } & \text { 13. Pulley } \\ \text { 5. Pulley } & \text { 14. Dudukan Motor } \\ \text { 6. Dudukan Motor } & \text { 15. Roda } \\ \text { 7. Roda } & \text { 16. Penampang Alat, } \\ \text { 8. Penampang Alat, } & \text { 17. Saluran Pembuangan } \\ \text { 9. Pulley } & \text { 18. Pisau Perajang }\end{array}$

Mesin Pencacah gedebog Pisang ini akan bekerja setelah motor listrik dihidupkan dan memutar poros yang ada pada motor tersebut yang juga akan memutar pulley yang ada pada ujung motor. Putaran tersebut akan ditransmisikan pada pulley poros mesin pencacah gedebog pisang melalui sabuk Vbelt sehingga memutar pulley yang terpasang pada poros mesin pencacah. Putaran pada poros mesin pencacah akan memutarkan pisau pencacah yang terpasang pada poros tersebut, sehingga pisau pencacah akan berputar. Selanjutnya gedebog pisang siap dimasukkan ke dalam lubang masukan (input) kemudian gedebog pisang akan digerakkan kedepan secara perlahan lahan menyesuaikan dengan pencacahan. Selanjutnya hasil cacahan gedebog pisang akan secara otomatis keluar melalui lubang keluaran (output).

\section{HASIL DAN PEMBAHASAN}

Perancangan komponen mesin adalah untuk memperhitungkan beban dan dimensi serta tegangan-tegangan yang terjadi agar mesin dapat bekerja dengan baik.

Perencanaan mesin pencacah gedebog pisang ini telah dihitung beberapa komponen terkait kekuatan, kebutuhan daya mesin serta perhitungan V-belt. Adapun perhitungan mekanis sebagai berikut 


\section{A. Perhitungan Komponen}

\section{Merencanakan Daya Motor}

Dengan batas maksimal yang direncanak beban $80 \mathrm{Kg}$. Perhitungan daya rencana sebagai berikut

Daya yang diperlukan

$$
\begin{aligned}
\mathrm{P} & =\frac{T / 1000(2 \cdot \pi \cdot n 2 / 60)}{102} \\
& =\frac{6800 / 1000(2.3,14 \cdot 500 / 60)}{102} \\
& =\frac{6,8 \cdot 52,3}{102} \\
& =\frac{355,64}{102} \\
& =3,5 \mathrm{~kW}
\end{aligned}
$$

Dengan mempertimbangkan Faktor keamanan daya rencana

$$
\begin{aligned}
P d \quad= & f . \\
& =1,4 \cdot 3,5 \\
& =4,9 \mathrm{~kW} \times 1,34 \\
& =6,5 \mathrm{HP}
\end{aligned}
$$

(satuan $(1,34)$ konversi ke Horse Power (Hp) dari daya yang dibutuhkan)

\section{Merencanakan Sabuk V dan Pulley}

Penenentuan tipe penampang sabuk dapat dilakukan dengan mengetahui daya rencana dan putaran motor.

$\mathrm{P}=3,5 \mathrm{~kW}$ (daya motor)

$\mathrm{n}=1200 \mathrm{rpm}$ (putaran motor)

$\mathrm{Fc}=1,4$ (faktor koreksi)

$\mathrm{Pd}=4,9 \mathrm{~kW}$ (daya rencana)

Berdasarkan diagram Pemilihan sabuk-V menurut Sularso, 1997[4], maka didapat penampang sabuk tipe A. Perencanaan perbandingan pulley yang akan digunakan adalah 1 : 2, maka diameter pulley yang digerakkan yaitu sebagai berikut :

Perbandingan reduksi menurut Sularso, 1997.[5] $i=\frac{n_{1}}{n_{2}}$

$=\frac{1200}{500}=2,4$

Keterangan :

$\mathrm{n}_{1}=$ putaran pulley penggerak (rpm)

$\mathrm{n}_{2}=$ putaran pulley yang digerakan (rpm)

Diameter nominal pulley yang digerakan (Sularso, 1997).

$$
\begin{aligned}
D_{p}= & d_{p} \cdot i \\
& =65 \cdot 2,4 \\
& =156 \mathrm{~mm}
\end{aligned}
$$

Keterangan :

$\mathrm{D}_{\mathrm{p}}=$ diameter nominal pulley digerakan $(\mathrm{mm})$

$\mathrm{d}_{\mathrm{p}}=$ diameter nominal pulley penggerak $(\mathrm{mm})$

Diameter luar pulley penggerak dan yang

digerakkan, Sularso, 1997[4]).

$$
\begin{aligned}
d_{k} & =d_{p}+2 \cdot \mathrm{k} \\
& =65+2 \cdot 4,5 \\
& =74 \mathrm{~mm}
\end{aligned}
$$

Dalam perhitungan perencanaan jarak sumbu poros adalah $\mathrm{C}=2 \times$ Dp yaitu $2 \times 156=312 \mathrm{~mm}$ dan jarak sumbu poros yang digunakan adalah $173 \mathrm{~mm}$ karena jarak sumbu poros pada perhitungan perencanaan terlalu panjang sehingga mempengaruhi lendutan yang terjadi pada poros, maka dicari :

Menghitung panjang keliling sabuk-V

$$
\begin{aligned}
L & =2 . C+\frac{\pi}{2}\left(d_{p}+D_{p}\right)+\frac{1}{4 \mathrm{C}}\left(D_{p}-d_{p}\right)^{2} \\
& =2.173+\frac{3.14}{2}(65+156)+\frac{1}{4.173}(156- \\
65 & )^{2} \\
& =346+346,97+12 \\
& =704,97 \mathrm{~mm}
\end{aligned}
$$

Keterangan :

$$
\begin{aligned}
& \mathrm{L}=\text { panjang } \mathrm{V} \text {-belt }(\mathrm{mm}) \\
& \mathrm{C}=\text { jarak antar poros }(\mathrm{mm}) \\
& \mathrm{D}_{\mathrm{p}}=\text { diameter pulley yang digerakan } \\
& (\mathrm{mm}) \\
& \mathrm{d}_{\mathrm{p}}=\text { diameter pulley penggerak }(\mathrm{mm})
\end{aligned}
$$

Hasil perhitungan perencanaan panjang sabuk-v yang diperoleh adalah $705 \mathrm{~mm}$, dari tabel panjang sabuk-v standart yang mendekati 705 $\mathrm{mm}$ adalah $686 \mathrm{~mm}$ atau sabuk no. $27 \mathrm{~L}=686$ mm. Tabel panjang sabuk-v dapat dilihat pada Tabel ukuran sabuk-v.

Menghitung jarak sumbu poros sabuk-V menurut Sularso, 1997[4]

$$
\begin{aligned}
\mathrm{b}= & 2 . \mathrm{L}-3,14\left(\mathrm{D}_{\mathrm{p}}+\mathrm{d}_{\mathrm{p}}\right) \\
= & 2.686-3,14(156+65) \\
= & 1372-693,94 \\
= & 678,06 \mathrm{~mm} \\
\text { Menghitung jarak poros } & \\
\mathrm{C}= & \frac{\mathrm{b}+\sqrt{\mathrm{b}^{2}-8\left(\mathrm{D}_{\mathrm{p}}-\mathrm{d}_{\mathrm{p}}\right)^{2}}}{8} \\
& =\frac{678,06+\sqrt{678,06^{2}-8(156-65)^{2}}}{8} \\
& =\frac{678,06+\sqrt{459765,36-66248}}{8} \\
& =\frac{678,06+\sqrt{393517,36}}{8} \\
& =\frac{678,06+627,3}{8} \\
& =163,17 \mathrm{~mm}
\end{aligned}
$$

Untuk mengetahui sudut kontak ( Sularso, 1991).

$$
\begin{aligned}
\theta & =180^{\circ}-\frac{57\left(\mathrm{D}_{\mathrm{p}}-\mathrm{d}_{\mathrm{p}}\right)}{\mathrm{C}} \\
& =180^{\circ}-\frac{57(156-65)}{163,17} \\
& =148,2^{\circ}
\end{aligned}
$$

Kecepatan linier sabuk V sebagai penerus daya dari motor bensin ke poros, dapat dihitung dengan rumus :

Kecepatan linier sabuk (Sularso, 1997). 
$\mathrm{V}=\frac{\pi \cdot \mathrm{d}_{\mathrm{p}} \cdot \mathrm{n} 1}{60.1000}$

$=\frac{(3,14) \cdot(65) \cdot(1200)}{60 \cdot 1000}$

60.1000

$=\frac{244920}{60000}$

$=4,1 \mathrm{~m} / \mathrm{s}$

Daya yang ditransmisikan oleh sabuk V.

$$
\begin{aligned}
f_{e} & =\frac{p_{o} \cdot 102^{2}}{\mathrm{~V}} \\
& =\frac{1,31 \cdot 102^{2}}{4,1} \\
& =\frac{133,62}{4,1} \\
& =32,6 \mathrm{~kg}
\end{aligned}
$$

Jumlah sabuk yang diperlukan (Sularso dan Suga, 1997).

$$
N=\frac{P_{d}}{P_{o} \times K_{\varnothing}}
$$

Diketahui : $P_{d}=4,9 \mathrm{~kW}$. Karena yang digunakan hanya $1 / 3$ dari daya rencana motor yang didapatkan maka didapat $1,63 \mathrm{~kW}$.

$$
\begin{aligned}
K_{\varnothing} & =0,93 \text { (factor koreksi) } \\
P_{O} & =1,16+0,15=1,31 \mathrm{~kW} \\
N & =\frac{1,63}{1,31 \times 0,93} \\
& =\frac{1,63}{1,22}
\end{aligned}
$$$$
=1,32 \text { buah sabuk }
$$

3. Menentukan Diameter Poros Torsi Penerus Daya

$$
\begin{aligned}
\mathrm{T} & =9,74 \times 10^{5} \frac{P d}{\mathrm{n}} \\
\mathrm{T} & =9.74 \times 10^{5} \frac{4,9}{1200} \\
& =\frac{4772600}{1200} \\
& =3977,2 \mathrm{~kg} \cdot \mathrm{mm}
\end{aligned}
$$

Tegangan geser yang diijinkan

$$
\text { (Sularso, 1997) }
$$

$$
\begin{aligned}
\tau_{a} & =\frac{\sigma_{t}}{S f_{1 . S f_{2}}} \\
& =\frac{59,3}{6,0.3,0} \\
& =\frac{59,3}{18} \\
& =3,3 \mathrm{~kg} / \mathrm{mm}^{2}
\end{aligned}
$$

Menghitung Diameter Poros

Faktor koreksi momen lentur adalah $\left(\mathrm{k}_{\mathrm{m}}\right)=$ 2,0

Faktor koreksi tumbukan $\left(\mathrm{k}_{\mathrm{t}}\right)=1,5$

Momen terbesar $(\mathrm{M})=2688 \mathrm{~N} / \mathrm{mm}$

$$
\begin{aligned}
& d_{s} \geq\left[\frac{5,1}{\tau_{a}} \cdot \sqrt{\left(K_{m} \cdot M\right)^{2}+\left(K_{t} \cdot T\right)^{2}}\right]^{1 / 3} \\
& d_{s} \geq\left[\frac{5,1}{3,3} \cdot \sqrt{(2,0.2688)^{2}+(1,5.3977,2)^{2}}\right]^{1 / 3}
\end{aligned}
$$

$$
\begin{aligned}
& d_{s} \geq\left[1,55 \cdot \sqrt{(5376)^{2}+(5965,8)^{2}}\right]^{1 / 3} \\
& d_{s} \geq[1,55 \cdot \sqrt{28901376+35590769,64}]^{1 / 3} \\
& d_{s} \geq[1,55 \cdot \sqrt{64492145,64}]^{1 / 3} \\
& d_{s} \geq[1,55 \cdot 8030,7]^{1 / 3} \\
& d_{s} \geq[12447,6]^{1 / 3} \\
& d_{s} \geq 23,2 \mathrm{~mm} \\
& \text { Poros yang digunakan berdiameter } \\
& 25 \mathrm{~mm} .
\end{aligned}
$$

\section{B. Proses pengerjaan}

Dalam membangun mesin pencacah gedebog pisang pengerjaan dibagi menjadi 3 komponen utama untuk memudahkan pekerjaan, yaitu : (1) Unit produksi. (2) Unit penggerak. (3) Unit Body. Tahapan pengerjaan pemotong dan penghitung bahan adalah sebagai berikut :

1. Persiapan bahan

Persiapan bahan yang akan digunakan yaitu dengan menggunakan besi stainles stell, besi siku 40x40x3, besi poros $\varnothing 25 \mathrm{~mm}$, plat $3 \mathrm{~mm}$, plat besi $7 \mathrm{~mm}$, plat besi $5 \mathrm{~mm}$, penyambungan bagian komponen dilakukan dengan menggunakan mesin las dan memakai mur dan baut.

2. Penandaan material

Proses penandaan material menggunakan alat ukur meteran dan mistar sorong, utuk penandaan material menggunakan pengores.

3. Pemotongan material

Hal yang perlu diperhatikan dalam pengerjaan pemotongan material adalah dengan melebihkan 1-2 mm untuk celah pemotongan. Maksudnya ialah pada saat proses pemotongan dengan mesin grinda atau alat potong yang lain tidak terjadi kekurangan ukuran pada saat proses pemotongan.

4. Penghalusan material

Setelah material sudah terpotong semua selanjutnya adalah proses penghalusan ujungujung material yang dipotong untuk menghilangkan bekas pemotongan dan agar tidak tajam pada sisi yang terpotong

5. Pemberian lubang

Proses pemberian lubang dengan menggunakan mesin bor tangan, ukuran mata bor yang digunakan adalah 8-12 mm. Pemberian lubang ini digunakan untuk proses perakitan yang menggunakan mur dan baut.

6. Perakitan

Setelah proses pemotongan, penghalusan, dan pemberian lubang selesai maka di lanjutkan dengan proses yang terakhir yaitu proses perakitan. Proses perakitan ini menggunakan mesin las listrik sesuai dengan perencanaan rancang bangun. 


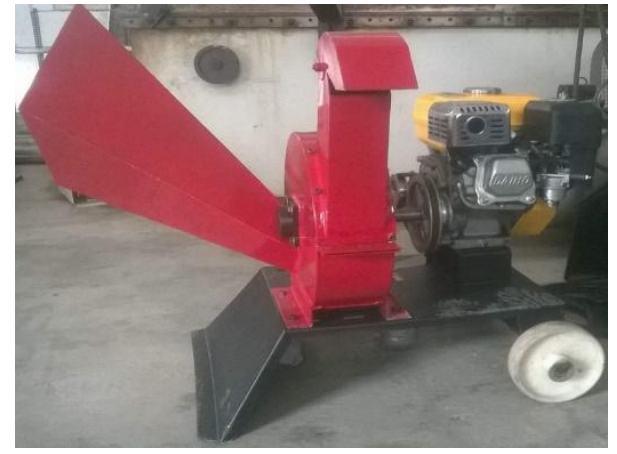

Gambar 3 Mesin Pencacah Gedebog Pisang

\section{Hasil Pengujian Mesin Pencacah}

Hasil potongan dari proses perajangan berupa potongan kecil - kecil dengan ukuran yang bervariasi. Dengan tebal maksimal potongan \pm 5 $\mathrm{mm}$. Berikut hasil potongan yang didapat setelah melakukan proses perajangan :

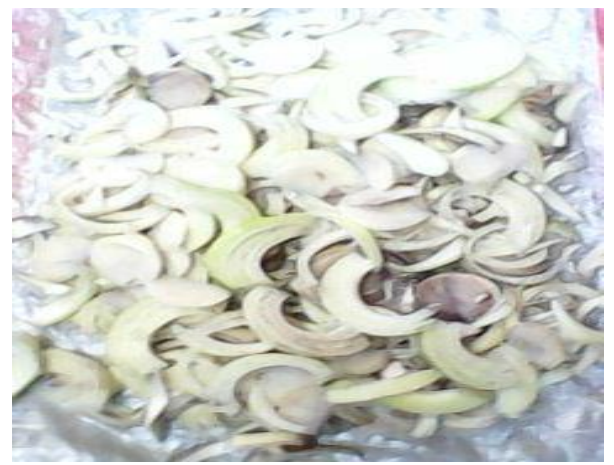

Gambar 3 Hasil Perajangan Gedebog Pisang

\section{Proses Pembuatan Pakan ternak dengan} teknik Fermentasi

Tahap kegiatan pelatihan pembuatan pakan ternak kambingi alternatif yang siap saji, urutan kerja pembuatan pakan ternak tersebut adalah seperti berikut:

1. Gedebog pisang tua yang telah ditebang, dihilangkan kulit luarnya lalu dicacah dengan ukuran 3-5 cm, kemudian dihamparkan selama 1-2 hari (untuk mengurangi kadar air

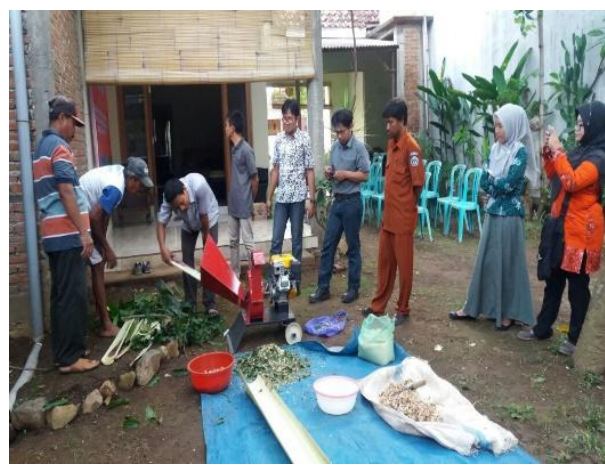

Gambar 4 Proses Pencacahan dengan mesin

2. Pada bagian lain, disiapkan campuran molase dan air (diusahakan air sumur) 1-2\% (10 cc molase dengan 0,2-1 L air), ditebarkan secara merata sejumlah $30-40 \%$ pada campuran cacahan gedebog pisang dan jerami padi (1:1) dan dedak padi $10 \%$, lalu diaduk secara merata;

3. Untuk memaksimalkan proses fermentasi bisa ditambahkan mikroorganisme aktif (1-2\%);

4. Setelah merata, kemudian dimasukkan ke dalam kantong plastik (silo) dan dipadatkan, lalu kantong plastik diikat kuat dan difermentasi selama 7 hari;

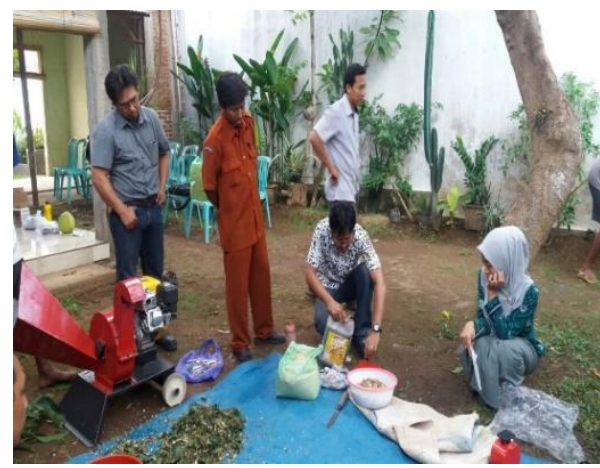

Gambar 5 Proses Pembuatan atau Pencampuran Bahan Fermentasi

5. Setelah menjalani proses selama 7 hari (ditandai bau asam manis), ikatan tali kantong plastik dibuka selanjutnya diangin-anginkan;

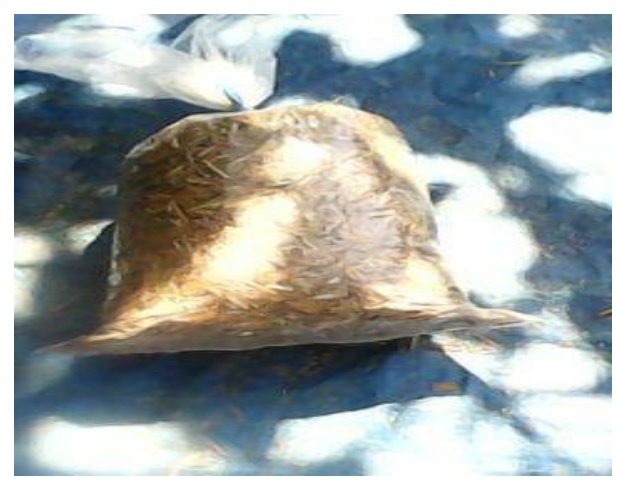

Gambar 6 Media Proses Selama Fermentas

6. Produk siap diberikan pada ternak kambing.

\section{KESIMPULAN}

\section{A. Kesimpulan}

Hasil perancangan mesin pencacah gedebog pisang untuk bahan baku pakan ternak dapat disimpulkan sebagai berikut :

1. Perencanaan daya motor sebesar 6,5 HP menggunakan diameter pulley penggerak 65 $\mathrm{mm}$ dan diameter pulley yang digerakkan 156 $\mathrm{mm}$, didapatkan putaran $500 \mathrm{rpm}$. Sistem transmisi menggunakan $V$-belt A. Diameter poros yang digunakan sebesar $25 \mathrm{~mm}$. Baut yang digunakan adalah M10.

2. Mesin Pencacah Gedebog Pisang akan berkerja ketika motor gasoline dinyalakan sehingga motor tersebut akan memutar poros yang ada pada motor yang juga akan memutar 
pulley yang ada pada motor listrik dan pulley yang ada pada poros pisau melalui perantara $V$-belt. Setelah pisau pencacah berputar, maka pisau pencacah akan memotong gedebog pisang yang dimasukkan secara perlahan-lahan pada lubang masukan atas (input) sehingga pencacahan gedebog pisang secara terus menerus akan mendapatkan hasil potongan yang diinginkan berbentuk potongan kecilkecil. Selanjutnya hasil pencacahan gedebog pisang akan secara otomatis jatuh dan keluar lewat lubang pengeluaran bawah (output).

\section{B. Saran}

Rancang Bangun Mesin Perajang Ranting Pohon dengan menggunakan motor bensin bertenaga 6,5 HP, getaran yang terjadi ketika proses sangatlah besar. Karena pada prosesnya daya yang digunakan hanya $1 / 3$ dari daya motor bensin. Jadi kelebihan daya tersebut mengakibatkan getaran yang besar.

\section{UCAPAN TERIMA KASIH}

Terima kasih kepada P3M Poliwangi yang telah membiayai kegiatan pengabdian masyarakat dengan pendanaan internal PNBP. Berterima kasih juga kepada mitra peternak kambing di kelurahan Sumberejo Banyuwangi

\section{DAFTAR PUSTAKA}

[1] L. Mott, Robert. 2009. Elemen-Elemen Mesin dalam Perancangan Mekanis Buku 1. PENERBIT ANDI.

[2] L. Mott, Robert. 2009. Elemen-Elemen Mesin dalam Perancangan Mekanis Buku 2. PENERBIT ANDI.

[3] Sato, G.Takesi. 1986. Menggambar Mesin Menurut Standar Iso. Jakarta: Pradnya Paramita

[4] Sularso. 2004. Elemen Mesin. Jakarta: PradnyaParamita.

[5] Sularso, Kiyokatsu Suga. 1991. Dasar Perencanaan dan Pemilihan Elemen Mesin, Cetakan ke 7, PT Pradnya Paramita, Jakarta.

[6] Sunyoto. 2008. Teknik Mesin Industri Jilid 1. Departemen Pendidikan Nasional. Jakarta.

[7] Taufik Rahman, Dikdik. 2014. Cara Membuat Pakan Kambing Atau Domba Dari Pohon Pisang

[8] I. Sunyoto, dkk, 2016. Kualitas Nutrisi Silase Limbah Pisang (batang dan Bonggol) dan Level Molases yang berbeda sebagai Pakan Ternak Alternatif Ternak Ruminansia. Jurnal Peternakan Vol 13 N0 2 September 2016

[9] https://organichcs.com/2014/01/31/4-cara membuatpakan-kambing-atau-domba-dari-pohon-pisang/. Diakses pada tanggal 10 februari 2016. 